\title{
DAMPAK PENGAMBILALIHAN BERITA KOTA OLEH MANAJEMEN WARTA KOTA TERHADAP PERSAINGAN BISNIS MEDIA CETAK DI JAKARTA
}

\author{
Eman Sulaeman Nasim \\ Institut Ilmu Sosial dan Manajemen STIAMI \\ emansnasim@gmail.com
}

\begin{abstract}
Abstrak. Media massa saat ini memegang peranan penting di tanah air. Selain berfungsi sebagai agen perubahan dan pembentuk opini publik juga sarana ekonomi dan bisnis yang menguntungkan. Salah satu perusahaan pers yang menguntungkan sehingga menjadi konglomerasi bisnis terkemuka di Indonesia adalah Kompas Gramedia Group. Selain mengelola media massa nasional, Kompas Gramedia juga mengelola koran-koran lokal. Warta Kota adalah salah satu koran lokal yang dimiliki Kompas Gramedia. Dalam rangka menguasai pasar pembaca di Ibu Kota sekaligus meraih kue iklan yang lebih besar, manajemen Warta Kota mengambilalih Koran Berita Kota yang sebelumnya dikelola PT Pena Mas Pewarta, dan menjadi pesaing utamanya. Pengambilalihan Koran Berita Kota hanya dilakukan dengan membeli merek Koran Berita Kota. Sementara PT Pena Mas Pewarta tidak dibeli. Penelitian ini, ingin melihat apakah yang dilakukan Pengelola Koran Warta Kota di atas bertentangan dengan Undang-undang No.5 Tahun 1999 Tentang Larangan Praktek Monopoli dan Persaingan Usaha Tidak Sehat, serta dapat mematikan iklim persaingan dan kompetisi yang sehat di bidang bisnis media massa cetak di wilayah Jakarta dan sekitarnya. Penelitian dilakukan menggunakan metode penelitian hukum empiris. Penelitian yang mengutamakan penelitian lapangan untuk memperoleh data primer sebagai data utamanya. Guna menunjang dan melengkapi data utama, dilakukan penelitian kepustakaan untuk memperoleh data sekunder. Terungkap tindakan hukum yang dilakukan pengelola Koran Warta Kota, selain untuk menghindari pengambilalihan tanggungjawab perusahaan Koran Berita Kota sebelumnya, juga sebagai upaya pihak Kompas Gramedia menghindari tindakan yang bertentangan dengan UndangUndang N0 5 Tahun 1999 Pasal 28 (2). Selain itu, Pengelola Koran Warta Kota telah melanggar Undang-undang No. 5 Tahun 1999 Bab IV Pasal 25 (1) serta telah melanggar Undang-undang No. 5 Tahun 1999 Bab IV Pasal 17 (2). Apa yang dilakukan Koran Warta Kota juga telah merugikan masyarakat pembaca Koran Berita Kota di DKI Jakarta dan sekitarnya.
\end{abstract}

Kata Kunci: Pengambilalihan Media Massa, Koran Berita Kota, dan Koran Warta Kota.

Abstract. Mass media currently plays an important role in the homeland. In addition to functioning as an agent of change and forming public opinion as well as economic and business facilities are profitable. One of the lucrative press companies to become the leading business conglomerate in Indonesia is Kompas Gramedia Group. In addition to managing the national mass media, Kompas Gramedia also manages local newspapers. Warta Kota is one of the local newspaper owned by Kompas Gramedia. In order to dominate the reader market in the capital city as well as to reach the larger advertising cake, the management of Warta Kota took over Kota Newspaper previously managed by PT Pena Mas Pewarta, and became its main competitor. The takeover of the City News newspaper is only done by purchasing the City News Newspaper. While PT Pena Mas Pewarta is not purchased. This research, want to see if what is done by Warta Karta Kota newspaper organizer is contradictory with Law No.5 of 1999 concerning Prohibition of Monopolistic Practices and Unfair Business Competition, and can turn off the competitive climate and healthy competition in print mass media business in Jakarta and surrounding areas. The research was conducted using empirical law research method. Research that prioritizes field research to obtain primary data as the main data. In order to support and complement the main data, conducted by library research to obtain secondary data. Revealed the legal action conducted by the newspaper Warta Kota, in addition to avoiding the takeover of corporate responsibility of the City News Newspaper 
previously, as well as efforts of Kompas Gramedia to avoid acts contrary to the Law NO 5 of 1999 Article 28 (2). In addition, the Newspaper News Manager has violated Law no. 5 of 1999 Chapter IV Article 25 (1) and has violated Law no. 5 of 1999 Chapter IV Article 17 (2). What the Koran Warta Kota has done has also harmed the readers of the Kota Berita Newspaper in DKI Jakarta and its surroundings.

Keywords: Mass Media Takeover, City News, and City News Newspaper.

\section{PENDAHULUAN}

Di era globalisasi informasi dan demokratisasi saat ini, media massa memegang peranan penting dalam kehidupan hukum, sosial, politik dan ekonomi di tanah air. Tidak sedikit anggota masyarakat yang berpendapat media massa berperan atau berfungsi sebagai pilar ke 4 (empat) dalam kehidupan berbangsa dan bernegara, setelah legislatif, eksekutif dan yudikatif. Hal ini karena media massa dapat mengarahkan perilaku suatu masyarakat untuk melakukan atau tidak melakukan sesuatu. Besarnya pengaruh media massa dalam kehidupan bermasyarakat dan bernegara sejalan dengan fungsi yang dimilikinya sebagaimana disampaikan Harold D. Laswell dan Charles Wright, menyebutkan media massa memiliki 4 fungsi sosial yaitu (1) pengamatan sosial (social surveillance), (2) korelasi sosial (social correlation), (3) sosialisasi (socialization), dan (4) hiburan (entertainment) (Naina, 2008: 463). Selain juga memiliki fungsi menyiarkan informasi (to inform), fungsi mendidik (to educate), fungsi menghibur (to entertain), dan fungsi mempengaruhi (to influence).

Fungsi mempengaruhi inilah yang seringkali dikaitkan dengan fungsi agenda setting. Tidak kalah pentingnya media massa juga berfungsi sebagai sarana memperkuat ekonomi dan bisnis. Itu sebabnya, banyak kelompok masyarakat khususnya kalangan pemilik modal, berlomba-lomba untuk ambil bagian mendirikan perusahaan pers. Ada kelompok masyarakat yang serius, sabar dan penuh ketekunan menggeluti dan menjalankan perusahaan pers. Ada juga yang sekedar ikut-ikutan baik karena pengaruh masa kampanye politik (pemilihan kepala daerah, pemilihan anggota legislatif dan pemilihan presiden), atau karena sakit hati sering diberitakan negatif oleh kelompok media massa lain, maupun karena ingin ikut menangguk keuntungan materi. Salah satu kelompok pemilik modal yang serius dan sabar dalam mengelola perusahaan pers sehingga menjelma menjadi institusi bisnis yang menguntungkan dan disegani di Indonesia adalah perusahaan pers Kompas Gramedia Group atau biasa dikenal dengan nama Kelompok Kompas Gramedia atau Kompas Gramedia Group.

Perusahaan pers yang sudah menjadi konglomerasi bisnis media ini kali pertama didirikan oleh PK Ojong dan Jakob Oetama. Menurut Sularto (2012: 94), Kelompok Usaha Kompas Gramedia ini, pertama kali didirikan pada tanggal 1 Juli 1963 melalui pendirian majalah Intisari oleh PK Ojong, Jakob Oetama serta Adisubrata. Selama berpuluh puluh tahun menguasai bisnis pers di tanah air mulai hulu seperti percetakan dan pabrik kertas hingga hilir seperti penerbitan, toko buku, jasa pengiriman, serta jasa penyelenggaraan pameran. Keberadaan perusahaan pers dengan ratusan media massa baik cetak maupun elektronik ikut menggerakan roda perekonomian daerah dan nasional di Indonesia. Ribuan tenaga kerja terserap sebagai karyawan dan ikut menikmati manisnya kegiatan ekonomi baik sebagai agen koran, pengecer, loper, biro iklan, sebagian lagi sebagai tenaga lepas (oursourching), serta bidang lainnya. Pendapatan yang diraup Kompas Gramedia Group bukan hanya dari penjualan atau sirkulasi baik berlangganan maupun membeli secara eceran melainkan juga dari pemasangan iklan. Pada 2010 saja, Kompas meraih iklan terbesar di surat kabar dengan nilai Rp 2,26 trliun selama 2010. Sementara Jawa Pos sebesar Rp 994 miliar, diikuti Seputar Indonesia sebesar Rp 950 miliar (Alif, 2010: 36). 
Eman Sulaeman Nasim, Dampak Pengambilalihan Berita Kota Oleh Manajemen Warta ...

Kelompok Usaha Kompas Gramedia juga mendirikan anak-anak perusahaan pers yang khusus mengelola koran, majalah, atau tabloid yang terbit dan diedarkan di daerah-daerah dan kota-kota besar di seluruh Indonesia. Salah satunya PT Metrogema Media Nusantara dengan produk yang diberi merek Warta Kota. Koran Warta Kota didirikan pada 1998 dikhususkan untuk memuat berbagai berita yang $80 \%$ berisi permasalahan metropolitan khususnya daerah Jakarta, Bogor, Depok, Tangerang, dan Bekasi (Jabodetabek). Sisanya berkaitan dengan permasalahan nasional dan sebagian kecil tentang masalah internasional. Koran Warta Kota ini menyasar pembaca yang tinggal di wilayah Jabodetabek dengan strata sosial ekonomi atas hingga menengah atau kelas $\mathrm{A}$, $\mathrm{B}$, hingga $\mathrm{C}$. Perusahaan pers ini juga mengelola, menerbitkan, mendistribusikan, dan pemasangan iklan. Sebelum Koran Warta Kota berdiri, sudah ada koran sejenis dengan oplah paling tinggi dan iklan baris paling banyak yaitu Koran Pos Kota diterbitkan PT Media Antar Kota Jaya beralamat di Jalan Gajah Mada No. 98 - 100 Jakarta Barat 11140. Koran ini milik mantan Menteri Penerangan, H. Harmoko dan juga mendirikan anak perusahaan yaitu Koran Harian Terbit khusus sore hari. Kedunya juga beredar di Jabodetabek dari kalangan kelas menengah ke bawah.

Lima tahun awal berdirinya Koran Warta Kota, pemasukan dari sirkulasi dan distribusi koran masih mengalami masa-masa sulit. Namun berkat pengalaman, kesabaran, dan keuletan manajemen dalam mengelola bisnis penerbitan juga didukung pendanaan yang kuat, Koran Warta Kota pun mampu melewati masa-masa sulit. Iklim bisnis di industri media massa memang tidak berbeda dengan iklim bisnis industri lain. Sebisa mungkin perusahaan menguasai pasar dan jika memungkinkan menjadi pemain tunggal dalam industri bisnis media untuk dapat mengeruk keuntungan sebesar-besarnya. Selama ini yang lazim terjadi, apabila perusahaan pers merasa terganggu dengan kehadiran produk media massa lain maka perusahaan tersebut akan membeli perusahaan pers pesaing sehingga berada di bawah kendalinya. Selanjutnya manajemen perusahaan pers yang membeli memutuskan apakah akan mematikan atau mengembangkan perusahaan pers tersebut. Apabila melihat media massa memiliki prospek sangat cerah dan membawa keberuntungan, maka perusahaan pers akan membeli media massa tersebut. Tak terkecuali dengan yang dilakukan Koran Warta Kota terhadap pesaing yakni Koran Berita Kota. Sebisa mungkin Koran Berita Kota dimatikan atau dimiliki sehingga pembaca tetap berada dalam kekuasaan Koran Warta Kota.

Ketika Koran Berita Kota sedang tinggi oplah dan pemasukan iklan dianggap menjadi pesaing Koran Warta Kota. Sehingga manajemen Koran Warta Kota melakukan langkah bisnis yang tak lazim. Yakni membeli merek Koran Berita Kota, sementara badan hukum (perusahaan) maupun saham perusahaan tidak dibeli. Karyawan dan para wartawan otomatis tidak bisa bekerja memproduksi Koran Berita Kota. Sejatinya, banyaknya kelompok bisnis yang menggeluti dan menjalankan perusahaan pers memberikan kesempatan yang lebih banyak lagi bagi masyarakat untuk bekerja di perusahaan pers. Hal ini juga memberikan sistem kompetisi yang fair di kalangan pengelola industri media untuk memberikan yang terbaik bagi para karyawan. Masyarakat mempunyai banyak pilihan untuk bekerja di perusahaan pers dan memilih yang lebih baik. Berdasarkan uraian Permasalahan di atas, dapat dirumuskan permasalahan penelitian sebagai berikut:

1. Apakah Pengambilalihan Koran Berita Kota dengan cara pembelian merek bertentangan dengan Undang-Undang No. 5 Tahun 1999 tentang Larangan Praktek Monopoli dan Persaingan Usaha Tidak Sehat?

2. Apakah pengambilalihan Koran Berita Kota dengan cara pembelian merek tanpa diikuti pembelian perusahaan dengan pengalihan karyawan dapat merugikan karyawan dan wartawan Koran Berita Kota? 
3. Apakah pembelian merek Koran Berita Kota oleh Koran Warta Kota bertentangan dengan Undang-Undang No. 40 Tahun 1999 tentang Pers?

\section{TINJAUAN PUSTAKA}

\section{Definisi Pers}

Bicara mengenai koran tidak terlepas dari kata maupun pengertian pers. Menurut Undang-Undang No. 40 Tahun 1999 tentang Pers (Kemenkominfo, 2011), pers adalah lembaga sosial dan wahana komunikasi massa yang melaksanakan kegiatan jurnalistik meliputi mencari, memperoleh, memiliki, menyimpan, mengolah, dan menyampaikan informasi baik dalam bentuk tulisan, suara, gambar, suara dan gambar, serta data dan grafik maupun dalam bentuk lainnya dengan menggunakan media cetak, media elektronik, dan segala jenis saluran yang tersedia. Koran menurut undang-undang tersebut adalah wahana komunikasi massa yang dalam Bahasa Inggris adalah mass media communication. Menurut Susanto (1988: 3), mass media communication atau mediated communication yakni komunikasi lewat media massa atau komunikasi dengan media massa. Dengan demikian, koran sebagai media cetak adalah wahana dari komunikasi itu sendiri. Sementara komunikasi adalah kegiatan pengoperan lambang-lambang.

\section{Tinjauan Wartawan dan Pekerja Pers}

Sebagai bagian dari pers nasional, media cetak menurut Undang-Undang No. 40 Tahun 1999 tentang Pers Pasal 5 (1), mempunyai kewajiban untuk memberitakan peristiwa dan opini dengan menghormati norma-norma agama dan rasa kesusilaan masyarakat serta asas praduga tak bersalah. Untuk menjalankan tersebut perusahaan pers memiliki karyawan tetap maupun lepas yang bertugas menulis dan menyampaikan berbagai peristiwa yang terjadi. Mereka biasa disebut sebagai wartawan atau jurnalis. Dalam undangundang tersebut khususnya Bab IV Pasal 10 juga dijelaskan bahwa "perusahaan pers memberikan kesejahteraan kepada wartawan dan karyawan pers dalam bentuk kepemilikan saham dan atau pembagian laba bersih serta bentuk kesejahteraan lainnya." Dengan demikian, apabila perusahaan pers ditutup atau berhenti beroperasi karena satu dan lain hal, maka pemilik atau manajemen perusahaan pers berkewajiban untuk memberikan uang jasa dan atau uang pesangon sesuai undang-undang dan peraturan pemerintah yang berlaku.

\section{Tinjauan Persaingan Bisnis}

Kata bersaing memiliki makna yang dapat diartikan sebagai tindakan yang bersifat individualistis dan hanya berorientasi pada kepentingan sepihak dengan cara melakukan berbagai cara dan upaya semaksimal mungkin untuk mencapai keuntungan yang sebesarbesarnya (Sirait, 2000: 15). Fenomena bersaing ini muncul secara alamiah di antara para pelaku bisnis di dunia usaha. Tidak terkecuali di dunia usaha atau industri media massa antara industri pers. Persaingan timbul secara alamiah untuk mendapatkan keuntungan yang sebesar-besarnya dari masyarakat konsumen dalam hal ini masyarakat pembaca dan masyarakat pemasang iklan. Sebagian besar perusahaan pers didirikan untuk mendapatkan keuntungan yang sebesar-besarnya. Dalam bukunya, Sirait (2010: 16) menyebut persaingan bisnis sebagai "situation in a market in which firmsor sellers independently strive for the partonage of buyyer in order to achieve a particular business objective e.g. profit, saled and/or market share.competition in this context is often equated with rivalry. Competitive rivalry between firm canoccur when there are tow price, quality, service or combination of these and other factors, which customer may value. Competition is viewed as an important process by which firms are forced to become effiecien and offer greater choice of product and services at lower prices. It gives rise to increases consumer welfare and allocative efficiency. It includes the conceft of 'dynamic effieciency" by which firms engage in inovations and foster technological change and progress."

\section{Hukum Persaingan Bisnis}


Pertumbuhan ekonomi Indonesia yang menggembirakan ditambah keterbukaan, demokratisasi, dan tingkat pendidikan masyarakat menjadikan industri pers di tanah air juga ikut berkembang meski tidak sedikit yang tutup tak melanjutkan usaha. Kondisi ini menciptakan persaingan di kalangan industri pers menjadi cukup tajam. Perusahaan pers yang sudah berdiri lama dan memiliki modal cukup dapat bertahan bahkan terus melebarkan sayap dan menguasai pasar lebih luas lagi. Sehingga tidak memungkinkan perusahaan pers lain dapat unggul dan mengalahkan persaingan bisnis di industri pers. Itu sebabnya hukum persaingan yang fair tetap diperlukan atau diberlakukan di tanah air. Hukum persaingan bisnis menjadi suatu elemen yang esensial sehingga kebutuhan hukum persaingan usaha mengarahkan pelaku usaha untuk bersaing secara sehat. Di samping memberikan landasan bagi persaingan usaha, negara juga mempunyai kebijakan persaingan untuk menjaga kelangsungan proses kebebasan yang diasosiasikan dengan freedom of trade, freedom of choice, access to market, dan berkembang ke freedom of voice.

Sejak reformasi 1998 pemerintah Indonesia mendukung adanya persaingan usaha yang sehat di antara para pelaku usaha. Baik kecil, menengah, maupun besar termasuk yang berstatus Badan Usaha Milik Negara (BUMN), Penanaman Modal Dalam Negeri (PMDN), berstatus Penanaman Modal Asing (PMA), maupun bentuk badan usaha lain. Munculnya UU No. 5 Tahun 1999 tentang Larangan Praktek Monopoli dan Persaingan Usaha Tidak Sehat ini tidak terlepas dari dorongan kuat masyarakat di era sebelumnya (Soeharto) dimana iklim bisnis dan usaha dipenuhi dengan praktek persaingan usaha yang kotor, curang, dan penuh monopolistik dari keluarga pejabat yang berkuasa di tingkat pusat maupun daerah. Iklim ini bukan hanya merugikan keuangan negara tapi juga mematikan potensi usaha masyarakat. Kehadiran UU tersebut untuk a) menjaga kepentingan umum dan meningkatkan efisiensi ekonomi nasional sebagai salah satu upaya untuk meningkatkan kesejahteraan rakyat; b) mewujudkan iklim usaha yang kondusif melalui pengaturan persaingan usaha yang sehat sehingga menjamin adanya kepastian kesempatan berusaha yang sama bagi pelaku usaha besar, usaha menengah, dan pelaku usaha kecil; c) mencegah praktek monopoli dan atau persaingan usaha tidak sehat yang ditimbulkan oleh pelaku usaha; dan d) terciptanya efektifitas dan efisiensi dalam kegiatan usaha. Sehingga pemerintah membentuk komisi independen yang disebut Komisi Pengawas Persaingan Usaha (KPPU) yang mengawasi dan menerima pelaporan dari masyarakat seputar adanya praktek persaingan usaha yang justru tidak sehat. Jika terbukti maka KPPU dapat menjatuhkan sangsi hukum, baik kurungan maupun denda kepada para pelaku usaha yang melakukan perbuatan curang.

\section{Persaingan Bisnis Media Cetak}

Pers di Indonesia umumnya dan wilayah Jabodetabek khususnya sudah menjadi industri dan bisnis. Hal ini karena besarnya kebutuhan masyarakat terhadap berbagai macam informasi terkait peristiwa lokal, nasional, maupun mancanegara dan informasi lain. Kebutuhan itu pula yang dimanfaatkan para pelaku bisnis untuk mendapatkan keuntungan yang besar. Berdasarkan pengamatan penulis, perusahaan pers yang dikelola secara profesional dan sungguhsungguh dapat mendatangkan keuntungan yang besar baik secara materi maupun yang lain bagi pengelola maupun pemilik. Persaingan bisnis media cetak menjadi semakin sengit dan berat dengan masuknya era media digital menambah persaingan bisnis media massa dan beralih ke media digital sebagai konsumsi informasi terkini. Sebagai entitas bisnis yang terlibat dalam industri dan persaingan usaha di sektor pers, seluruh perusahaan terikat dalam Undang-Undang No. 5 Tahun 1999 tentang Larangan Praktek Monopoli dan Persaingan Usaha Tidak Sehat. Karena itu, dalam menjalankan persaingan usaha para pelaku usaha pers tetap dilarang melanggar undang-undang tersebut. Persaingan bisnis yang dapat dilakukan hanya dalam rangka memperoleh pembaca maupun 
iklan dengan tetap harus memperhatikan koridor persaingan yang sehat.

\section{Definisi Pengambilalihan}

Kata pengambil alihan berasal dari kata, ambil. Menurut kamus besar Bahasa Indonesia yang dikeluarkan Pusat Bahasa Kementrian Pendidikan Nasional (2008: 48), kata ambil mengandung arti, pegang lalu dibawa. Kata mengambil mengandung arti sebagai sesuatu lalu dibawa, diangkat, digunakan. Sementara kata pengambilan berarti proses, cara perbuatan mengambil. Kata ambil alih adalah bentuk kata kerja yang berarti terima dari orang lain untuk dikerjakan atau ditindak lanjuti. Sedangkan kata pengambilalihan mengandung arti proses, cara perbuatan mengambil alih. Dengan demikian, kalimat pengambilalihan Koran Berita Kota oleh Koran Warta Kota menurut penulis adalah cara perbuatan mengambil alih atau proses perbuatan mengambil alih. Proses di sini adalah perbuatan hukum yang dilakukan sebelum orang maupun institusi mengambil untuk ditindaklanjuti. Karena ada kata proses, berarti ada perbuatan atau tindakan hukum yang disepakati kedua belah pihak berdasarkan hukum dan perundangan yang berlaku di Republik Indonesia.

\section{Kompas Gramedia Group, Koran Warta Kota, dan Koran Berita Kota}

Bicara Koran Warta Kota tidak terlepas dari kelompok usaha bernama Kompas Gramedia Group. Selain menerbitkan dan mengedarkan Koran Kompas serta Koran Warta Kota, Kompas Gramedia Group juga menerbitkan dan mengedarkan media cetak lain yakni koran seperti Tribun, juga majalah dan tabloid terkemuka seperti National Geographic, National Geographic Kids, Majalah Potret Negeri Ku, Intisari, Princess, Barbie, Cars, Bobo, Bobo Junior, Kawanku, Tabloid Nova, dan Majalah CHIP. Kompas Gramedia Group juga mengelola media daring seperti Kompas.com, Tribunnews.com. Termasuk mengelola Kompas TV dan bekerjasama dengan perusahaan Trans Corporations serta radio seperti Sonora dan Motion Radio. Selain bidang pers, konglomerasi bisnis yang dinakhodai Agung Adiprasetyo memiliki dan mengelola perusahaan penerbitan Gramedia Printing serta memiliki 6 jaringan toko buku seperti Toko Buku Gramedia, Toko Buku Media Bookstore, dan Toko Buku Trimedia Bookstore. Juga memiliki 7 jaringan penerbit buku seperti Elex Media Komputindo, Penerbit Buku Kompas, Kepustakaan Populer Gramedia (KPG), Gramedia Widiasarana Indonesia (Grasindo), M\&C, dan Level Comics. Kompas Gramedia Group juga menjadi pemilik dan pengelola perusahaan pameran dan event organizer terkemuka Dyandra Promosindo, jaringan Hotel Santika dan Amaris, memiliki dan mengoperasikan pabrik kertas koran dan tisu. Selain itu, Kompas Gramedia Group menjadi pemilik dan pengelola dua lembaga pendidikan terkemuka yakni ELTI dan Universitas Multimedia Nusantara (www.kompasgramedia.com).

Sementara Koran Warta Kota yang dikelola PT Metrogema Media Nusantara merupakan satu anak perusahaan dari Kompas Gramedia Group. Koran tersebut terbit di Jakarta setiap hari dengan tema bebas meskipun basisnya tetap pada berita perkotaan dengan pembahasan pada segala masalah yang terjadi atau berkaitan dengan persoalan perkotaan dan segala tingkah pola manusia. Pilihan menu antara olahraga, selebritas, dan hot topics. Menurut website resmi Kompas Gramedia, Harian Warta Kota sengaja didirikan untuk menjadi media khas bagi warga Jabodetabek dan sekitarnya yang menjadi panduan dalam melihat dan menjalani hak dan kewajiban. Media cetak ini menjadi jembatan sesama masyarakat, antara masyarakat dengan pemerintah, dan semua aparat yang memberikan pelayanan. Termasuk menjadi medium yang mempertemukan masyarakat sebagai konsumen dengan berbagai penyedia jasa pelayanan, perdagangan, industri, hiburan, dan semua kebutuhan mereka.

Sejak 2008, Koran Berita Kota terbit di bawah naungan Kompas Gramedia Group. Isi berita juga tidak berbeda jauh dengan Koran Warta Kota, hanya saja perbedaan terletak 
Eman Sulaeman Nasim, Dampak Pengambilalihan Berita Kota Oleh Manajemen Warta ...

pada jumlah halaman dan harga per eksemplar. Koran Berita Kota juga menjadi sarana komunikasi yang menjalankan fungsi pers di bawah badan hukum PT Pena Mas Pewarta milik pengusaha bernama Rudi Susanto yang bergerak di bidang jasa hiburan seperti karaoke dan panti pijat. Perusahaan PT Pena Mas Pewarta beserta alamat redaksi terletak di Jalan Suryopranoto 1-9 B1 A/44 45, Petojo Selatan, Gambir Jakarta Pusat 10160 Jakarta dengan nomor telepon (021) 3803027. Koran tersebut terbit kali pertama sekitar 1999. Sebelum diambilalih Kompas Gramedia Group, koran ini lebih menitik beratkan pemberitaan terhadap permasalahan metropolitan seperti tindak kejahatan atau kriminal perkotaan, penataan kota, hiburan malam, olah raga dan sebagian kecil berita kebijakan politik, ekonomi, pertahanan, dan keamanan nasional. Menurut data Media Scene (2011) jumlah oplah Koran Berita Kota menduduki urutan ke 5 setelah Koran Kompas, Top Skor, Pos Kota, dan Koran Warta Kota. Sementara bila diurutkan sesama koran kota, Koran Berita Kota menduduki peringkat ke 3 setelah Koran Pos Kota dan Koran Warta Kota. Peringkat tersebut merupakan prestasi tersendiri mengingat usia koran kurang dari 12 tahun dibandingkan dengan yang lebih tua seperti Media Indonesia, Bisnis Indonesia, Republika, Suara Pembaruan, Rakyat Merdeka, Lampu Hijau, dan Koran Jakarta.

\section{METODE PENELITIAN}

Penelitian yang dilaksanakan ini merupakan penelitian hukum empiris. Penelitian hukum empiris adalah penelitian yang mengutamakan penelitian lapangan untuk memperoleh data primer sebagai data utamanya. Guna menunjang dan melengkapi data, maka dilakukan penelitian kepustakaan yaitu penelitian yang dilakukan dengan cara studi pustaka untuk memperoleh data sekunder. Penelitian hukum itu sendiri adalah proses untuk menemukan aturan hukum, prinsip-prinsip hukum, maupun doktrindoktrin hukum guna menjawab isu hukum yang dihadapi. Hal ini sesuai dengan karakter preskriptif ilmu hukum. Penelitian hukum dilakukan untuk menghasilkan argumentasi, teori atau konsep baru sebagai preskripsi dalam menyelesaikan masalah yang dihadapi (Marzuki, 2010: 35). Jawaban yang diharapkan dalam penelitian hukum adalah right, appropriate, inappropriate, atau wrong. Dengan demikian dapat dikatakan bahwa hasil yang diperoleh di dalam penelitian hukum sudah mengandung nilai.

Penelitian ini termasuk dalam penelitian hukum empiris karena penelitian ini menggunakan data hasil wawancara maupun pandangan pelaku proses Pengambilalihan Koran Berita Kota oleh manajemen Koran Warta Kota, dalam hal ini manajemen PT Metrogema Media Nusantara, sebagai salah satu anak perusahaan Kompas Gramedia. Selain itu, penelitian ini juga menggunakan data hasil wawancara dan pandangan dari wartawan Koran Berita Kota yang dikelola PT Pena Mas Pewarta, redaktur Koran Warta Kota, pengamat komunikasi dan media massa, juga pendapat dan pandangan anggota masyarakat pembaca koran Berita Kota serta pelaku industri perusahaan periklanan. Hal yang cukup penting dalam penelitian hukum sebagai suatu kegiatan ilmiah adalah proses analisa yang meliputi metode, sistematika dan pemikiran tertentu yang bertujuan untuk mempelajari gejala tertentu dan kemudian mengusahakan pemecahan atas masalah yang timbul (Soekanto, 1986: 43). Walaupun menurut Mertokusumo (2010; 36), penelitian hukum berbeda dengan penelitian sosial lainnya. Ilmu sosial berhubungan dengan apa yang ada, meneliti kebenaran fakta, bukan apa yang seharusnya. Ilmu sosial menjawab pertanyaan bagaimana dan mengapa sesuatu itu demikian. Tujuannya adalah untuk menderminasi pola logis dari keajegan dalam kehidupan sosial. Ilmu Sosial tidak memasalahkan nilai. Ada asumsi fundamental bahwa hidup ini teratur bukan merupakan khaos.

Jika ditinjau dari sifatnya, penelitian yang penulis lakukan ini masuk ke dalam penelitian deskriptif analitis. Yaitu dengan menerangkan dan menjelaskan secara terinci dan sistematis tentang permasalahan, dilanjutkan dengan analisa terhadap masalah tersebut. Penelitian 
deskriptif itu sendiri adalah penelitian yang mempelajari masalah-masalah dalam masyarakat serta tata cara yang berlaku dalam masyarakat serta situasi situasi tertentu termasuk hubungan, kegiatan-kegiatan, sikapsikap, pandangan-pandangan, serta proses yang sedang berlangsung dan pengaruhpengaruh dari suatu penomena yang sedang berlangsung dan pengaruh-pengaruh dari suatu fenomena (Nazir, 2002: 54). Selain itu, penelitian ini bersifat deskriftif karena hasil penelitian ini diharapkan dapat menggambarkan secara menyeluruh dan sistematis mengenai asas asas hukum, kaidah kaidah hukum, dan doktrin serta peraturan perundang-undangan. Bersifat analistis karena hasil penelitian ini akan dilakukan analisis terhadap berbagai aspek hukum yang mendasari dan mengatur tentang persaingan usaha di bidang media massa cetak. Berdasarkan hal tersebut, maka data yang dibutuhkan dalam penelitian ini adalah data sekunder dan data primer yang diperoleh dari penelitian kepustakaan dan penelitian lapangan.

Ada dua jenis data yang digunakan dalam penelitian ini, yaitu data primer dan data sekunder. Sementara, data sekunder yang digunakan dalam penelitian ini berasal dari studi literatur, buku, artikel internet, kliping pemberitaan, undang-undang yang berkaitan atau berhubungan dengan penelitian ini. Untuk mendapatkan data primer dan data sekunder diadakan dua jenis penelitian. Adapun dua jenis penelitian itu adalah:

a. Penelitian kepustakaan, yaitu penelitian dengan menggunakan sumber-sumber tertulis yang berupa perundangundangan, buku-buku, berita dan artikel di media massa baik cetak maupun media online (portal berita), Kamus Besar Bahasa Indonesia, dan tulisan-tulisan lain yang dianggap berhubungan dan dapat memberikan data tambahan mengenai obyek penelitian. Obyek penelitian di sini tidak lain adalah Proses Pengambil alihan Koran Berita Kota oleh Manajemen Koran Warta Kota. Yang terpenting dalam penelitian ini tentu saja adalah sumber bahan hukum. Adapun yang menjadi sumber bahan hukum adalah peraturan perundang-undangan.

b. Bahan hukum sekunder yang berkaitan erat dalam menjelaskan permasalahan meliputi buku-buku atau literatur-literatur daro para ahli dan atau para akademisi. Juga bahan hukum tersier yang memberikan petunjuk maupun penjelasan terhadap bahan hukum primer dan sekunder. Bahan hukum tersier yang dipakai dalam penelitian ini antara lain Kamus Besar Bahasa Indonesia

Lokasi penelitian yang dipilih ada di wilayah Daerah Khusus Ibukota (DKI) Jakarta dengan teknik pengumpulan sampel berasal dari informan atau nara sumber dalam penelitian ini dipilih berdasarkan metode purposive sampling. Di dalam metode ini peneliti memutuskan sendiri informan berdasarkan tujuan penelitian ini dan untuk menemukan data sebanyak mungkin. Dengan demikian, diharapkan peneliti dapat menggali dengan lebih mendalam dari informan yang dipilih. Adapun teknik pemilihan yang digunakan adalah maximum variation, guna mewakili keseluruhan khalayak secara lebih dekat. Maximum variation adalah teknik pemilihan informan di mana informan tersebut sengaja dipilih dari pengaturan yang mewakili berbagai pengalaman yang terkait dengan fenomena yang menarik perhatian peneliti.

Dalam penelitian ini, penulis mengambil sampel sebanyak 10 informan sebagai narasumber yang dinilai mewakili pendapat para pihak yang menjadi obyek penelitian. Antara lain dari pimpinan Koran Warta Kota, pimpinan Koran Berita Kota, wartawan senior kedua media cetak, organisasi profesi wartawan, akademisi, pengusaha, pembaca, dan aktifis LSM. Teknik pengumpulan data dilakukan dengan wawancara, yaitu tanya jawab secara langsung tentang permasalahan yang ada dengan menggunakan alat yakni pedoman wawancara yaitu urutan langkahlangkah wawancara dan daftar pertanyaan yang untuk wawancara. Pengolahan data yang digunakan adalah dengan cara pemeriksaan data (editing), pendataan data (coding), klasifikasi data (clasification), dan 
Eman Sulaeman Nasim, Dampak Pengambilalihan Berita Kota Oleh Manajemen Warta ...

penyusunan data (systematizing). Setelah data terkumpul selanjutnya dilakukan analisis data dengan cara menggambarkan keadaan sebenarnya di lapangan. Karakteristik penelitian kualitatif ini dilakukan pada kondisi yang alamiah, lebih bersifat deskriptif, lebih mengutamakan proses, melakukan analisis data secara induktif, dan lebih menekankan makna (data dibalik yang teramati).

\section{ANALISA DAN PEMBAHASAN}

Pada 2010 di Jabodetabek, khususnya DKI Jakarta terdapat 20 koran dengan merek yang berbeda, baik berskala nasional maupun lokal yang terbit dan beredar dan dijual secara berlangganan maupun secara eceran. Antara lain Kompas, Bisnis Indonesia, Republika, Seputar Indonesia, Media Indonesia, Koran Tempo, Rakyat Merdeka, Kontan, Suara Pembaruan, Sinar Harapan, Indopos, Warta Kota, Pos Kota, The Jakarta Post, Berita Kota, Lampu Hijau, Koran Jurnal Nasional, Koran Jakarta, Harian Terbit, Harian Neraca, Harian Ekonomi Investor Daily, Radar Bogor, Radar Depok, Radar Bekasi, dan Jurnal Bogor. Sebagian besar dimiliki beberapa konglomerasi media seperti Kompas Gramedia Group, Jawa Pos Group, Tempo Media Group, MNC Group.

Dari sekian banyak koran yang terbit, hanya lima koran yang khusus beredar di Jabodetabek dengan jumlah oplah dan pembaca terbanyak. Yaitu Pos Kota dengan 638.000, Warta Kota sebanyak 540.000, Berita Kota yakni 360.000, Lampu Hijau yaitu 244.000, dan Radar Bogor 171.000. Koran Berita Kota masuk ke dalam tiga besar yang paling banyak dibaca masyarakat setelah Koran Warta Kota. Koran Berita Kota menempel ketat Koran Warta Kota. Dibandingkan yang lain manajemen beserta jajaran redaksi Koran Berita Kota dikatakan berhasil membangun nama dan kredibilitas yang baik di mata pembacanya. Sehingga kepercayaan masyarakat terhadap Koran Berita Kota semakin meningkat. Selain oplah yang tinggi, Koran Berita Kota diakui, Wakil Pemimpin Redaksi Koran Warta Kota (pesaing) sudah mempunyai nama.
Pertimbangan membeli Koran Berita Kota adalah Koran Berita Kota yang sudah mempunyai pembaca tetap. Meskipun samasama Koran Metropolitan, namun Koran Berita Kota dan Koran Warta Kota mempunyai segmen pembaca yang berbeda. Pembaca Koran Berita Kota lebih banyak beretnis Chinese yang tersebar di Jakarta Barat, Jakarta Utara dan Jakarta Pusat serta sebagian di luar wilayah Jakarta. Sementara Koran Warta Kota mempunyai pembaca yang fanatik di wilayah Jakarta Selatan, Jakarta Timur, Jakarta Pusat, Tangerang, dan Bogor.

Selain memiliki pembaca cukup fanatik dan oplah cukup spektakuler, Koran Berita Kota juga memiliki pemasang iklan tetap untuk masyarakat menengah ke bawah. Seperti iklan obat perkasa atau iklan obat kuat untuk laki-laki. Iklan ini berbeda dengan yang biasa dipasang di Koran Warta Kota. Namun, kondisi manajemen Koran Berita Kota ternyata tidak sebagus yang diduga masyarakat. Pemilik Koran Berita Kota mengaku pusing dalam menjalankan bisnis mengingat pemilik adalah pengusaha yang menggeluti bisnis hiburan dan bukan pengusaha yang sejak awal menekuni bisnis media atau mantan wartawan. Pemilik mengaku perusahaan rugi karena pemasukan iklan sangat sedikit sementara gaji karyawan cukup besar. Alasan itu yang membuat keputusan sejak akhir 2009 Koran Berita Kota mulai ditawarkan ke beberapa perusahaan seperti Koran Warta Kota. Namun, penjelasan tersebut dibantah mantan wartawan Koran Berita Kota. Menurutnya perusahaan dalam keadaan baik dan banyak iklan. Bahkan sampai ada yang berani memasang iklan di halaman pertama.

Bukti lain menunjukkan bahwa Koran Berita Kota sedang tidak merugi. Karena pembayaran gaji, Tunjangan Hari Raya (THR) beserta bonus bagi karyawan tidak pernah terlambat dibayarkan. Alasan dari penjualan Koran Berita Kota bukan pada kerugian, melainkan karena faktor lain seperti naiknya harga kertas karena bisnis industri pers tersebut sering terganggu dengan pihak berwajib karena berita di Koran Berita Kota. Manajemen juga tidak bagus dimana kontrol 
dari pemilik tidak berjalan. Ketidakjujuran dan ketidakterbukaan manajemen Koran Berita Kota terhadap pemilik juga diketahui ketika pemilik selesai melakukan transaksi jual beli merek Koran Berita Kota. Ketika pemilik menawarkan sisa kertas yang akan dijadikan untuk penerbitan, perwakilan Koran Warta Kota menyatakan penawaran dengan harga yang sangat tinggi, padahal pemilik sudah memberikan diskon cukup besar. Ketika dijelaskan harga kertas koran di pasaran yang ternyata jauh lebih rendah menjadikan pemilik Koran Berita Kota menyadari kalau selama ini dibohongi. Siapapun yang membeli Koran Berita Kota akan untung. Hanya saat itu kondisi manajemen berantakan. Termasuk bagian iklan yang mengatakan diskon pemasang iklan $90 \%$.

Ketika Koran Warta Kota akan membeli merek Koran Berita Kota, kondisi perusahaan sedang dalam kondisi sangat bagus. Dari sisi aset, Koran Warta Kota selain memiliki anak perusahaan juga dari segi statsus sosial ekonomi, segmen pembaca pada kelas A, B, dan C. Rata-rata dari kalangan berpunya dan berpendidikan hingga kalangan masyarakat menengah bawah. Juga dari keuntungan pemasukan iklan yang menjadi Koran sudah dipercaya. Selain itu dari segi budaya perusahaan, Koran Warta Kota juga mengharuskan seluruh karyawan untuk selalu mengutamakan kejujuran. Apabila tercium indikasi tersebut manajemen Koran Warta Kota langsung meminta mereka mengundurkan diri. Dari segi pemberitaan, Koran Warta Kota juga diharuskan selalu mengutamakan cover both side dan tidak boleh berpihak kepada salah satu pihak, khususnya yang sedang berkonflik.

Alasan Koran Warta Kota berminat mengambilalih Koran Berita Kota ingin menguasai pembaca di beberapa DKI Jakarta karena sudah eksis. Koran Berita Kota sudah memiliki pembaca yang fanatik dengan sebagian besar dari etnik Chinese. Jika dikelola secara benar, maka pendapatan yang diperoleh cukup bagus. Bahkan alasan dari manajemen Koran Warta Kota juga tidak ingin diganggu oleh keberadaan Koran Berita
Kota. Lebih jauh, maka pembahasan konten bagi Koran Warta Kota dititikberatkan sebagai koran berita hiburan, sosial, dan kebijakan pemerintah sedangkan Koran Berita Kota lebih ditekankan kepada berita politik, kriminal, dan olah raga. Dengan kalimat lain pembelian merek Koran Berita Kota memiliki unsur keuntungan, persaingan, dan efisiensi. Karena saat itu Koran Warta Kota memiliki redaktur dan wartawan berjumlah 40 orang yang dianggap cukup dan mampu menghandle 2 media cetak. Artinya mengelola Koran Berita Kota hanya membutuhkan biaya untuk penambahan kertas dan penambahan beberapa orang redaktur. Sisanya dikelola oleh manajemen yang sama dan justru semakin banyak meraih keuntungan dari biaya pemasangan iklan.

Perbedaan kualitas karyawan dan budaya perusahaan juga sudah dilakukan terlebih dulu melalui pengkajian dan penelitian terhadap kualitas sumber daya manusia di Koran Berita Kota. Hasilnya sangat berbeda yakni kurang bagus dan sudah melekat serta mendarah daging dalam kehidupan sehari-hari dan jika diambilalih juga akan membahayakan sistem dan budaya kerja yang telah dibangun di lingkungan Kompas Gramedia Group. Terlebih dalam membuat berita tidak sesuai kode etik jurnalistik dan kode etik penulisan berita di lingkungan Kompas Gramedia Group seperti tidak menggunakan cover both side. Bahkan pihak Koran Berita Kota suka melakukan pemerasan terhadap pengusaha dan perusahaan kemudian memberitakan negatif ketika tidak dituruti. Ketika diambilalih oleh Kompas Gramedia Group ada beberapa pimpinan perusahaan yang mengucapkan terima kasih sebab sering diperas oleh oknum Koran Berita Kota. Namun begitu pihak Koran Warta Kota tetap memberikan kesempatan kepada mantan karyawan Koran Berita Kota untuk bekerja di bawah manajemen Koran Berita Kota yang baru melalui hasil seleksi ulang dan diberikan pelatihan.

Untuk proses negosiasi dan biaya pembelian merek dimulai sejak akhir 2009, mengingat Koran Berita Kota saat itu sudah eksis sehingga menguntungkan apabila 
dikelola secara baik. Keputusan dan inisiatif membeli Koran Berita Kota ada pada pemimpin umum dan pemimpin redaksi Koran Warta Kota untuk melakukan tawar menawar. Akan tetapi keputusan tertinggi tetap pada pimpinan Kompas Gramedia Group. Rencana pembelian Koran Berita Kota pada Desember 2009 baru direalisasikan pada Januari 2010 pada kisaran angka Rp 10 miliar rupiah. Jumlah tersebut termasuk pembayaran kewajiban pesangon, gaji, dan bonus yang harus diberikan pemilik lama Koran Berita Kota kepada para karyawan Koran Berita Kota dengan total sekitar 150 orang. Walau demikian, uang tersebut sifatnya pinjaman dari Kompas Gramedia Group kepada Koran Warta Kota sebagai pengelola.

Tanggapan mantan karyawan Koran Berita Kota mengaku sedih, marah, dan kecewa atas sikap Kompas Gramedia Group yang membeli merek Koran Berita Kota dan berpendapat hal ini merupakan bentuk 'pembosaian' Koran Berita Kota terhadap persaingan bisnis yakni Koran Warta Kota. Tindakan ini dapat dikategorikan sebagai persaingan bisnis yang tidak sehat untuk menghindari persaingan di pasar sehingga dibeli. Sebelumnya karyawan Koran Berita Kota mendapat rumor tentang rencana penjualan Koran Berita Kota. Namun tidak sedikit karyawan yang belum mengetahui rencana tersebut hingga akhirnya pemilik Koran Berita Kota memberikan penjelasan bahwa keesokan hari Koran Berita Kota sudah terbit di bawah bendera Koran Warta Kota. Sikap ini menyebabkan karyawan Koran Berita Kota dibawah manajemen lama kehilangan pekerjaan dan puluhan karyawan beberapa kali mengadakan aksi protes di depan Kompas Gramedia Group. Pihak Koran Warta Kota dan manajemen Kompas Gramedia Group selalu menemui dan mengajak diskusi sekaligus menjelaskan proses pembelian merek Koran Berita Kota kepada para mantan karyawan yang mengadakan aksi protes.

Tawaran kerja, pembayaran pesangon, dan hak-hak karyawan pada saat manajemen Koran Warta Kota melakukan pembayaran atas pembelian merek Koran Berita Kota sudah diingatkan seluruhnya. Sehingga tidak ada lagi karyawan Koran Berita Kota yang dirugikan. Terhadap pesan dan permintaan manajemen Koran Warta Kota tersebut telah disetujui oleh pihak pemilik Koran Berita Kota. Sehingga pembayaran gaji, pesangon, dan biaya-biaya lain masuk dalam biaya pembelian sebesar Rp 10 miliar yang sudah dibayarkan oleh pihak Koran Warta Kota. Bagi karyawan Koran Berita Kota manajemen lama dipersilakan oleh manajemen Koran Warta Kota untuk tetap memberikan kesempatan kerja. Namun tetap harus mengikuti proses seleksi dan training yang dilakukan oleh divisi sumber daya manusia Koran Warta Kota dan Kompas Gramedia Group. Akan tetapi karena muncul perasaan kecewa dan sakit hati, hanya beberapa karyawan dari Koran Berita Kota yang memenuhi tawaran dari Koran Warta Kota. Yakni dengan mengajukan lamaran dan mengikuti semua proses seleksi.

Intinya, Koran Warta Kota tidak merekrut secara otomatis semua karyawan dari Koran Berita Kota. Alasannya Koran Warta Kota hanya membeli merek Koran Berita Kota dan bukan membeli perusahaan pers dari Koran Berita Kota. Namun demikian, tidak semua karyawan di Koran Berita Kota mengaku mendapatkan semua hak, melainkan hanya gaji dan pesangon saja. Adapun tunjangan dan bonus tidak didapat lantaran tak ada kesempatan untuk berdiskusi lagi. Selama bekerja di Koran Berita Kota, seluruh karyawan dengan total mencapai 150 orang pada dasarnya mendapatkan hak seperti gaji, Tunjangan Hari Raya (THR), bonus, dan pembagian dividen. Namun ketika merek Koran Berita Kota dibeli Koran Warta Kota berdampak para karyawan di Koran Berita Kota kehilangan pekerjaan dan mengaku tidak mendapatkan apa yang menjadi hak dan apa yang mereka harapkan. Pesangon yang diberikan tidak sesuai dengan UU No. 13 Tahun 2013 tentang Ketenagakerjaan, dimana mereka hanya menerima berdasarkan tahun lama bekerja dikalikan gaji plus uang kearifan 1 bulan gaji.

Untuk format Koran Berita Kota setelah di bawah manajemen yang baru dan meski 
terjadi pergantian kepemilikan merek Koran Berita Kota sekaligus pergantian karyawan yaitu redaktur dan wartawan yang meliput dan menulis berita, pergantian tersebut tidak menjadikan Koran Berita Kota berhenti beroperasi atau berhenti beredar meskipun hanya satu hari. Pada saat masih berlangsung negosiasi harga, manajemen Koran Warta Kota sudah menyiapkan dummy sehingga begitu persetujuan jual beli merek ditandatangani, keesokan harinya Koran Berita Kota dengan pemilik dan manajemen baru sudah terbit dan beredar di masyarakat. Hal ini karena sebelumnya sudah matangmatang dipersiapkan simulasi Koran Berita Kota dengan rubrik yang sama. Bahkan sudah dipersiapkan simulasi selama dua minggu sebelum terjadi transaksi pembelian.

Setelah Koran Berita Kota diambilalih dan dikelola oleh Koran Warta Kota, oplah Koran Berita Kota mengalami kenaikan, akan tetapi mengalami penurunan di bidang iklan. Sebelum Koran Berita Kota diambil alih oleh Koran Warta Kota memiliki banyak pemasang iklan. Akan tetapi karena iklan tersebut lebih banyak berkaitan dengan keperkasaan atau obat kuat jelas hal itu tidak sesuai dengan prinsip yang dipegang oleh manajemen Kompas Gramedia Group. Maka iklan-iklan tersebut dihapus. Meskipun tidak sedikit para pemasang iklan sudah mengikat kontrak dengan manajemen Koran Berita Kota yang lama dalam jangka waktu yang panjang. Sehingga karena putus kontrak, maka pihak manajemen Koran Berita Kota lama harus membayar kompensasi. Di luar iklan obat perkasa, pemasukan iklan dari corporate atau jenis produk lain juga mengalami penurunan. Penurunan iklan tersebut selain karena ada anggapan, Koran Berita Kota merupakan duplikasi Koran Warta Kota juga karena divisi Iklan dari Koran Warta Kota menurunkan grade masyarakat pembaca Koran Berita Kota yang semula ditujukan untuk masyarakat kelas A, B, dan C seperti Koran Warta Kota diubah menjadi grade $\mathrm{C}$ dan $\mathrm{D}$. Penurunan status sosial pembaca ini yang menjadikan pemasang iklan akhirnya mundur untuk kembali melakuk kontrak. Dimana, para pemasang iklan lebih suka memasang iklan di koran yang dibaca kelompok masyarakat kelas A dan B yang dianggap potential buyers.

Awalnya Koran Berita Kota dibeli oleh Koran Warta Kota untuk penajaman berita. Dimana Koran Warta Kota lebih kepada berita tentang hiburan, sosial, dan kebijakan. Sementara Koran Berita Kota lebih ditekankan kepada berita politik, kriminal, dan olah raga. Namun, pihak divisi iklan melakukan perubahan, dengan merubah grade masyarakat pembaca dari yang semula pembacanya sama dengan Koran Warta Kota diubah ke pembaca dengan status ekonomi lebih rendah yakni grade $\mathrm{C}$ dan D. Perubahan itu menjadikan pemasangan iklan menjadi berkurang cukup drastis. Hingga akhirnya pada 2013, manajemen Kompas Gramedia Group memasukan manajemen Tribun News. Manajemen Tribun adalah manajemen yang mengelola Koran Tribun di berbagai wilayah di Indonesia dan juga mengelola portal berita Tribun News. Tribun merupakan salah satu anak perusahaan pers Kompas Gramedia Group. Menurut manajemen Tribun tidak boleh ada dua bendera di tempat yang sama.

Selain itu, kalau Koran Berita Kota dan Koran Warta Kota sama akan muncul permasalahan di Iklan. Pemasukan dari iklan menjadi tidak bagus karena harus ada diferensiasi yang berbeda. Setelah dilakukan kajian, ternyata pembaca Koran Berita Kota lebih banyak menyukai berita olah raga atau sepak bola. Karena itu dilakukan perubahan, namanya menjadi Berita Kota Super Ball pada Maret 2014. Akan tetapi, ketika Koran Berita Kota diubah namanya menjadi Berita Kota Super Ball dengan porsi berita lebih banyak kepada olah raga khususnya sepak bola untuk menyaingi Koran Top Skor justru jumlah oplah yang ada malah turun. Semula nama Koran Berita Kota akan dihilangkan dan diganti dengan Super Ball dan rencana tersebut berubah karena melihat hasil riset AC Nielsen. Dimana Koran Berita Kota mempunyai segmen pembaca yang loyal.

Berdasarkan hasil riset AC Nielsen, di wilayah Jabodetabek Koran Berita Kota menempati posisi 9, sementara Koran 
Eman Sulaeman Nasim, Dampak Pengambilalihan Berita Kota Oleh Manajemen Warta ...

Kompas menempati peringkat 1 diikuti oleh Koran Jawa Pos, lalu Koran Pos Kota, Koran Warta Kota, Koran Seputar Indonesia, Koran Republika, Koran Media Indonesia, dan Radar Bogor. Sedangkan di peringkat nasional, Koran Berita Kota menempati posisi ke 14 sementara Koran Warta Kota menduduki peringkat ke 8. Hingga saat ini Koran Berita Kota bernama Berita Kota Super Ball. Adapun konten berita akan lebih banyak tentang olah raga khususnya sepak bola. Koran ini menyamai Koran Top Skor yang memiliki banyak pembaca di wilayah Jakarta dan sekitarnya.

Diambilnya Koran Berita Kota oleh Koran Warta Kota atau konglomerasi Kompas Gramedia Group, menurut pengusaha yang juga pimpinan salah satu perusahaan periklanan, selain meningkatkan pemasangan iklan di Koran Berita Kota, juga dapat mematikan perusahaan pers yang mengelola koran lain. Meskipun pemasangan iklan berbentuk corporate meningkat di Koran Berita Kota namun peningkatan itu masih jauh lebih kecil dibandingkan jumlah pemasangan iklan di koran induknya, Harian Umum Kompas. Pembelian Koran Berita Kota oleh Kompas Gramedia tersebut mematikan perusahaan pers lainnya terutama perusahaan-perusahaan yang masih kecil dan merugikan karena masyarakat mendapat berita yang dimungkinkan sama, tidak ada perbedaan dari versi lain dari Koran Berita Kota.

Untuk perubahan format Koran Berita Kota sejak diambil Kompas Gramedia Group menjadi Koran Berita Kota Super Ball merugikan pembaca. Alasannya, jika Koran Berita Kota sebelum 2010 berita kriminalitas yang ada sangat lengkap selain itu cara penyajian juga lebih tajam. Tapi pemberitaan yang sekarang lebih banyak keseragaman bahkan lebih banyak mengarah ke berita bola. Sebelum 2010 cara penyajian lebih tajam dan jenis berita yang ditampilkan juga bermacammacam. Sehingga pembaca mendapatkan informasi yang banyak dari membaca Koran Berita Kota. Pihak pembaca media cetak, khususnya Koran Berita Kota dan Warta Kota mengetahui meski judul berita kedua media memiliki kesamaan namun ulasan dan perspektif penulisan yang ada relatif berbeda sehingga memperkaya pembaca. Hal ini yang belum tentu ditemukan saat ini. Namun, bagi pembaca Koran Berita Kota versi lama hanya lebih banyak menemukan semua berita kriminal. Namun, sekarang lebih banyak berita tentang olah raga sepak bola. Sebagai penggemar olah raga sepak bola tentu mengaku lebih menyukai Koran Berita Kota saat ini yang sudah dikelola oleh Koran Warta Kota. Selain harga Koran Berita Kota sebesar Rp 1.500 juga sebagai harga yang terjangkau bagi semua pihak, apalagi bagi mereka yang sehari-hari hanya memiliki profesi yang biasa.

Sebagai akademisi, ada perbedaan dalam mengomentari peralihan manajemen Koran Berita Kota ke Koran Warta Kota. Pengamat media massa dari Jurusan Komunikasi Fakultas Ilmu Sosial dan Ilmu Universitas Indonesia (FISIP UI) Ade Armando berpendapat pembelian Koran Berita Kota oleh Kompas Gramedia Group khususnya hanya pada merek tanpa aset, perusahaan, dan karyawan bukanlah suatu tindakan yang dapat dikatakan tidak adil. Menurutnya, perlu dikaji secara lebih jauh bagaimana kesepakatan jual beli yang memang disetujui oleh kedua belah pihak antara Kompas Gramedia Group dengan perusahaan pemilik Koran Berita Kota. Pembelian Berita Kota semata-mata adalah pembelian atas nama Koran Berita Kota itu sendiri. Soal keadilan atas nasib karyawan tentu tergantung kepada pemilik perusahaan meski pemilik perusahaan memang tidak boleh semena-mena terhadap karyawan. Karena yang berpindahtangan adalah SIUP dan akta perusahaan, bukanlah aset dan karyawan. Ada beberapa alasan mengapa seseorang atau suatu institusi membeli media lain. Ketika Kompas Gramedia Group membeli Koran Berita Kota, banyak orang mempertanyakan mengapa harus membeli koran tersebut. Jika tujuan untuk mengurangi kompetitor, meski Koran Berita Kota telah dibeli namun orang-orang dibalik media tersebut dapat membuat koran lain dengan judul berbeda. Maka, dapat dikatakan penbelian Kompas Gramedia 
Group atas Koran Berita Kota bukanlah untuk melonggarkan persaingan.

Justru dengan merger dan akuisisi adalah kecenderungan yang sangat lazim ditemui jika media tumbuh menjadi industri. Hal ini sesuai dengan kecenderungan ke arah monopolistis. Akan terdapat integrasi vertikal dan horizontal dalam industri media massa. Setiap perusahaan tidak cukup dengan mmeiliki satu produk media massa karena untuk menjangkau seluruh pasar maka perusahaan media harus memenuhi semua segmen dalam masyarakat misalnya satu produk untuk suatu kelas dalam masyarakat. Misalnya untuk kelas menengah ke atas dan menengah ke bawah ditawarkan dua produk yang berbeda meski dinaungi oleh satu perusahaan yang sama. Memang ada kekhawatiran bahwa jika akhirnya media-media yang banyak itu dikuasai oleh segelintir orang, maka dapat terjadi pengurangan keragaman opini. Konten menjadi semakin terseragamkan kepentingannya. Lebih lanjut Ade juga menjelaskan meski pemain banyak dan seperti saling bersaing, namun karena dikuasai oleh sedikit perusahaan maka dapat berbahaya terhadap hak masyarakat untuk memperoleh informasi yang beragam dan lebih jauh lagi dapat pula mengancam demokrasi.

Lebih lanjut Ade Armando berpendapat setelah intergrasi antar perusahaan media, tentu masuk kepada prinsip semakin besar suatu perusahaan maka ia akan semakin kuat dalam menghadapi pesaing-pesaing kecil. Masuk pula pada economic of scale, semakin perusahaan besar maka akan dapat mengefisienkan biaya produksi sementara perusahaan-perusahaan tidak memiliki efisiensi itu. Perusahaan kecil akan kesulitan dan mati satu persatu. Kompas Gramedia Group sebagai perusahaan media yang besar competitive advantage, yaitu dengan memiliki satu alat produksi yang sama, dapat digunakan bersama-sama oleh empat koran miliknya dan inilah yang disebut pula dengan konglomerasi media massa yang semakin mengancam keragaman berita di pasar yang pada akhirnya dapat pula mengancam demokrasi.
Berdasarkan penjelasan narasumber Ade Armando, pembelian merek Koran Berita Kota adalah bagian dari strategi besar Kompas Gramedia untuk menguasai pasar maupun masyarakat pembaca yang berada di DKI Jakarta pada khususnya dan di Bogor, Depok, Tangerang, dan Bekasi pada umumnya. Keputusan membeli merek Koran Berita Kota bukan hanya diputuskan oleh pemimpin redaksi dan pemimpin perusahaan Koran Warta Kota, tapi juga diputuskan dan disetujui oleh pemimpin umum Kelompok usaha pers Kompas Gramedia Group. Apalagi dana Rp 10 miliar rupiah juga diperoleh dari Kompas Gramedia Group dalam bentuk pinjaman. Strategi besar itu adalah menguasai pasar pembaca dan pemasang iklan di wilayah DKI Jakarta dan sekitarnya. Selain itu merek koran yang dibeli sekaligus dimatikan adalah Koran Berita Kota yang selama ini telah menjadi pesaing utama dari Koran Warta Kota milik Kompas Gramedia Group. Koran Berita Kota selama beberapa tahun terakhir selain menjadi pesaing utama Koran Warta Kota, juga telah menjelma menjadi Koran yang memiliki pelanggan tetap atau fanatik, memiliki pemasang iklan yang tetap, serta telah menjadi koran yang menguntungkan. Kondisi ini tentu saja mengkhawatirkan Pihak Kompas Gramedia Group pemilik dari Koran Warta Kota. Jika dibiarkan, bukan tidak mustahil, Koran Berita Kota akan dapat menggeser kedudukan koran Warta Kota.

Langkah hukum yang diambil pihak Kompas Gramedia Group mengambil alih Koran Berita Kota dengan cara hanya membeli merek Koran Berita Kota bukan dengan cara mengambil alih Koran Berita Kota beserta badan hukum, aset dan karyawan selain untuk menghindari resiko menanggung hutang hutang yang dimiliki manajemen maupun perusahaan, juga menghindari kewajiban terhadap para karyawan Koran Berita Kota yang lama. Kompas Gramedia Group melalui manajemen Koran Warta Kota sudah melakukan kajian, meski Koran Berita Kota telah menjadi koran yang memiliki pembaca yang fanatik dan banyak pemasang iklannya, namun attitude maupun mental dan kualitas sumber daya manusia yang dimiliki 
Eman Sulaeman Nasim, Dampak Pengambilalihan Berita Kota Oleh Manajemen Warta ...

berbeda dengan mental, attitude serta kualitas sumber daya manusia yang selama ini telah bekerja dan digembleng secara baik di lingkungan Kompas Gramedia Group. Seperti soal kejujuran di bidang keuangan, kejujuran di bidang penulisan, kejujuran dalam bersikap sebagai wartawan yang harusnya selalu independen dan profesional serta tidak menerima apalagi meminta imbalan. Adanya pernyataan dari pemilik Koran Berita Kota yang lama, bahwa korannya selalu rugi, padahal selama ini Koran Berita Kota adalah koran yang memiliki pembaca dan pemasang iklan yang fanatik, sudah menjadi kecurigaan dari pihak manajemen Koran Warta Kota dan Kompas Gramedia Group terhadap kejujuran dan mentalitas dari pengelola Koran Berita Kota yang lama.

Selain itu adanya pihak-pihak tertentu yang mengaku sering 'diperas' oleh pihak Koran Berita Kota (yang lama) menunjukkan kurang profesionalnya wartawan Koran Berita Kota dibandingkan wartawan media massa yang ada dibawah kendali Kompas Gramedia Group. Hal itu dipertimbangkan membawa resiko tersendiri bagi manajemen Koran Warta Kota apabila memberli Koran Berita Kota beserta perusahaan yang otomatis harus menampung karyawan. Dengan hanya membeli merek Koran Berita Kota saja manajemen Koran Warta Kota maupun Kompas Gramedia Group sebagai induk perusahaan tidak dapat dipersalahkan apabila tidak secara otomatis merekrut karyawan. Manajemen Koran Warta Kota juga tidak dapat dipersalahkan bila setelah pembelian merek Koran Berita Kota, sebagian besar karyawan Koran Berita Kota yang lama pada akhirnya harus menerima tindakan hukum berupa pemutusan hubungan kerja alias PHK. Namun demikian, manajemen Koran Warta Kota dan Kompas Gramedia Group sudah mengingatkan kepada pemilik merek Koran Berita Kota untuk melindungi hak-hak karyawan Koran Berita Kota setelah dikelola Koran Warta Kota sebagai akibat dari dibelinya merek Koran Berita Kota.

Pihak Koran Warta Kota sendiri memberikan kesempatan kepada karyawan Koran Berita Kota untuk melanjutkan karirnya baik sebagai staf administrasi maupun wartawan, setelah lulus dari serangkaian tes yang diselenggarakan pihak Kompas Gramedia Group. Dari sekian banyak karyawan dan wartawan Koran Berita Kota (yang lama) setidaknya terdapat tiga wartawan yang lulus tes dan akhirnya melanjutkan karir sebagai wartawan di Koran Berita Kota yang dikelola oleh Koran Warta Kota sebagai anak perusahaan Kompas Gramedia Group. Dengan sendirinya, tidak ada Undang-Undang Ketenagkerjaan yang dilanggar oleh pihak Koran Warta Kota maupun Kompas Gramedia Group.

Namun dilihat dari Undang-Undang No. 5 Tahun 1999 tentang Larangan Praktek Monopoli dan Persaingan Usaha Tidak Sehat, tindakan hukum yang dilakukan Kompas Gramedia melalui anak perusahaan, Koran Warta Kota dengan melakukan pembelian merek untuk selanjutnya mengoperasikan Koran Berita Kota yang sebelumnya adalah koran pesaing untuk menghindari pengambilalihan tanggungjawab perusahaan atau koran Berita Kota sebelum juga sebagai upaya pihak Kompas Gramedia Group menghindari tindakan yang bertentangan dengan pasal 28 (2). Dimana menyebutkan pelaku usaha dilarang melakukan pengambilalihan saham perusahaan lain apabila tindakan tersebut dapat mengakibatkan terjadinya praktek monopoli dan atau persaingan usaha tidak sehat". Namun demikian, apa yang dilakukan Kompas Gramedia Group melalui anak perusahaan Koran Warta Kota tidak bisa dipisahkan dari Bab IV Bagian IV tentang Posisi Dominan. Bagian Pertama Pasal 25 (1) poin c disebutkan pelaku usaha dilarang menggunakan posisi dominan baik secara langsung maupun tidak langsung untuk menghambat pelaku usaha lain yang berpotensi menjadi pesaing untuk memasuki pasar yang bersangkutan. Selnjutnya pada ayat 2 dijelaskan pelaku usaha memiliki posisi dominan sebagaimana dimaksud ayat 1 apabila (a) satu pelaku usaha atau satu kelompok pelaku usaha menguasai $50 \%$ atau lebih pangsa pasar satu jenis barang atau jasa tertentu. Kompas Gramedia Group saat ini 
menguasai lebih dari $50 \%$ masyarakat pembaca ibu kota juga pangsa iklan. Selain juga Kompas Gramedia Group di bidang media massa cetak sudah memiliki posisi dominan.

Sementara Koran Warta Kota memiliki pangsa pasar pembaca yang bila digabungkan dengan Koran Berita Kota memiliki jumlah lebih dari $50 \%$. Sehingga Koran Berita Kota dan Koran Warta Kota akan memiliki posisi dominan dan apa yang dilakukan Kompas Gramedia Group telah melanggar bab IV pasal 25 ayat 1 . Dengan dibelinya merek Koran Berita Kota oleh Koran Warta Kota, lalu mengoperasikan dan mengelola Koran Berita Kota menggantikan Koran Berita Kota (lama) namun tetap dengan format dan tampilan yang hampir sama, berarti Kompas Gramedia Group menguasai pasar pembaca koran di DKI Jakarta lebih dari 50\%. Apa yang dilakukan Kompas Gramedia Group ini juga telah merugikan masyarakat pembaca koran kota, khususnya yang ada di DKI Jakarta dan Jabodetabek pada umumnya. Karena sebelumnya masyarakat Jabodetabek memiliki alternatif informasi tentang kondisi kota yang berbeda yakni dari Koran Berita Kota dan dari Koran Warta Kota melalui gaya penulisan yang berbeda dan ulasan yang berbeda.

Namun sejak Koran Berita Kota dibeli oleh Koran Warta Kota namun pengelolaan dilakukan oleh satu dapur redaksi dengan wartawan yang sama, maka informasi dan penyajian beritanya juga sama. Hanya gaya bahasa yang diubah. Hal ini tentu saja merugikan masyarakat pembaca karena masyarakat tidak dapat memilih koran yang menyajikan laporan atas berbagai peristiwa dari sudut pandang yang berbeda. Setelah Koran Berita Kota dan Koran Warta Kota dikelola oleh satu dapur redaksi yang sama di Koran Warta Kota maka sudut pandang dan penyajian juga menjadi sama. Pemilik Koran Berita Kota selain menawarkan penjualan Koran Berita Kota kepada Koran Warta Kota serta kepada manajemen Kompas Gramedia Group, juga menawarkan kepada PT MNC atau RCTI yang antara lain mengelola Koran Seputar Indonesia. Sekiranya MNC Group yang membeli Koran Berita Kota dalam rangka membidik pasar masyarakat pembaca ibu kota, jelas Koran Seputar Indonesia tidak akan terjebak dalam persaingan bisnis tidak sehat dan tidak dianggap melanggar UndangUndang No. 5 Tahun 1999 tentang Larangan Praktek Monopoli dan Persaingan Usaha Tidak Sehat. Hal ini karena Koran Seputar Indonesia belum memiliki koran kota seperti Koran Warta Kota yang dimiliki Kompas Gramedia Group. Sementara Kelompok Jawa Pos sudah memiliki yakni bernama Indopos serta Koran Radar Bogor.

\section{KESIMPULAN DAN SARAN}

\section{Kesimpulan}

Berdasarkan uraian-uraian tersebut disimpulkan beberapa poin, yaitu:

1. Pengambilalihan Koran Berita Kota oleh Koran Warta Kota dengan cara membeli merek Koran Berita Kota merupakan tindakan yang tidak dapat terhindar dari dugaan adanya pelanggaran UndangUndang No. 5 Tahun 1999 tentang Larangan Praktek Monopoli dan Persaingan Usaha Tidak Sehat Bab IV Pasal 17 (2).

2. Pengambilalihan Koran Berita Kota oleh Koran Warta Kota dengan cara membeli merek tanpa membeli perusahaan sekaligus tanpa mengalihkan karyawan merugikan sebagian karyawan. Sebagian besar karyawan baik yang bekerja sebagai wartawan maupun non wartawan kehilangan mata pencaharian atau pekerjaannya.

3. Apa yang dilakukan manajemen Koran Warta Kota dalam melakukan pengambilalihan Koran Berita Kota tidak melanggar Undang-Undang No. 40 Tahun 1999 tentang Pers sebab peraturan itu tidak menyinggung tata cara pembelian maupun pengambilalihan perusahaan media massa.

\section{Saran}

Adapun saran yang diberikan sebagai berikut: 
Eman Sulaeman Nasim, Dampak Pengambilalihan Berita Kota Oleh Manajemen Warta ...

1. Ke depan Komisi Pengawasan dan Persaingan Usaha (KPPU) yang telah dibentuk harus dapat bekerja dengan lebih baik dan lebih keras lagi dalam mengawasi persaingan bisnis dan usaha di industri pers. Sehingga praktek monopoli atau oligopoli dan persaingan bisnis tidak sehat dapat dicegah.

2. Sebagai konglomerasi pers yang sudah besar dan disegani, Kompas Gramedia Group maupun Jawa Pos Group dan yang lain seharusnya memberikan kesempatan kepada masyarakat khususnya kalangan pemodal menengah dan kecil untuk bersama-sama aktif dan berpartisipasi dalam bisnis dan pengelolaan pers.

3. Saat ini banyak perusahaan pers yang bermodal kecil tidak masuk dalam kelompok perusahaan pers yang besar, belum menjalankan sistem manajemen yang baik dan transparan. Sehingga peristiwa penggelapan dana keuntungan oleh beberapa pimpinan perusahaan masih terjadi. Selain merugikan pemilik juga karyawan dan wartawan. Untuk itu, tidak ada salahnya pemerintah melalui Kementerian Usaha Kecil Menengah dan Koperasi maupun melalui Kementerian Informasi dan Komunikasi dapat membantu manajemen perusahaan pers yang mandiri untuk memiliki manajemen usaha yang lebih baik. Namun tidak melakukan intervensi atas kebijakan redaksional.

\section{DAFTAR PUSTAKA}

Alif, M. Gunawan. (2011). Dinamika Media dan Pertumbuhan Pesat Periklanan. Media Scenethe Official Guide to Advertising Media in Indonesia. Jakarta: Perhimpunpunan Perusahaan Periklanan Indonesia (PPPI).

Clear. A. Weiderman L. (2004). Dynamic of Public Relations and Journalism: a Practial Guide for Media Studies. Cape Town: Juta Academic.

CST, Kansil. (1989). Pengantar Ilmu Hukum dan Tata Hukum Indonesia. Jakarta: Balai Pustaka.
Effendi, Oyong Uchyana. (1994). Hubungan Masyarakat, Suatu Studi Komunikasi. Bandung: PT Remaja Rosdakarya.

Hapriyani, Richka. (2011). Pers, Kekuatan Politik Keempat yang Dikuasai Pengusaha.

Kadir, Muhammad Abdul. (2004). Hukum dan Penelitian Hukum. Bandung: Citra Aditya Bakti.

Marzuki, Peter Mahmud. (2010). Penelitian Hukum. Jakarta: Kencana Prenada Media Group.

Nazir, Mohammad. (2002). Metode Penelitian. Jakarta: Ghalia Indonesia.

Naina, Akhmadsyah et al. (2008). 75 Tahun M Alwi Dahlan: Manusia Komunikasi, Komunikasi Manusia. Jakarta: Kompas.

Lattimore, Dan et al. (2010). Public Relation Profesi dan Praktik. Edisi 3. Jakarta: Salemba Humanika.

Sirait, Ningrum Natasya. (2010). Hukum Persaingan di Indonesia UU No. 15/1999 tentang Larangan Praktek Monopoli dan Persaingan Usaha Tidak Sehat. Medan.

Soekanto, Soerjono. (1986). Pengantar Penelitian Hukum. Jakarta: UI Press.

Soekanto, Soerjono, dan Sri Mamudji. (2003). Penelitian Hukum Normatif Suatu Pengantar Singkat. Jakarta: PT Raja Grafindo Persada.

Sularto, ST. (2012). Syukur Tiada Akhir Jejak Langkah Jakob Oetama. Jakarta: PT Penerbit Buku Kompas.

Susanto, Astrid S. (1988). Komunikasi dalam Teori dan Praktek. Bandung: Penerbit Binacipta.

Theaker, A. (2004). The Public Relations Handbook Second Editions. Oxfordshire: Routledge.

Undang-Undang No. 05 Tahun 1999 tentang Larangan Praktek Monopoli dan Persaingan Usaha Tidak Sehat.

Undang-Undang No. 40 Tahun 1999 tentang Pers dan Media Massa.

Undang-Undang No. 15 Tahun 2001 tentang Merek.

Undang-Undang No. 13 Tahun 2003 tentang Ketenagakerjaan.

Undang-Undang No. 40 Tahun 2007 tentang Perseroan. 
Jurnal Ilmiah Ilmu Administrasi

ISSN 2085-1162

Undang-Undang No. 14 Tahun 2008 tentang Keterbukaan Informasi Publik

Undang-Undang Dasar Negara Republik Indonesia Tahun 1945. Amandemen Keempat. 